\title{
POSICIONAMENTOS DO LOCUTOR-ENUNCIADOR EM CONTEXTOS DE IMPUTAÇÃO DA RESPONSABILIDADE ENUNCIATIVA NO TEXTÓ ACADÊMICO-CIENTÍFICO'
}

\author{
POSITIONS OF SPEAKER/ENUNCIATOR IN CONTEXT OF \\ IMPUTATION OF ENUNCIATIVE RESPONSABILITY ON ACADEMIC- \\ SCIENTIFIC TEXTS
}

Rosângela Alves dos Santos Bernardino²

\begin{abstract}
RESUMO: O trabalho investiga a responsabilidade enunciativa em textos acadêmicos produzidos por pesquisadores iniciantes, buscando especificamente descrever e interpretar os posicionamentos enunciativos do primeiro locutor-enunciador (L1/ E1) quando da imputaçâo de pontos de vista (PdV) a enunciadores segundos (e2). Teoricamente, o trabalho pauta-se nos postulados da Análise Textual dos Discursos (ATD), conforme Adam (2011), em articulaçăo com o estudo de Guentchéva (1994), as observaçōes de Authier-Revuz $(1998,2004)$ sobre a heterogeneidade enunciativa, entre outros autores. Nos textos analisados, mostrou-se mais recorrente a expressáo de posicionamentos favoráveis por parte de L1/E1, em situaçôes de retomadas, reformulaçóes e comentários que reafirmam e validam o dizer do outro. Os resultados revelam que o pesquisador iniciante instaura uma forma de diálogo com os PdV alheios, direcionado para a construçấo de um laço de responsabilizaçăo compartilhada.
\end{abstract}

PALAVRAS-CHAVE: responsabilidade enunciativa; artigo científico; pesquisador iniciante; imputaçăo; posicionamento enunciativo.

ABSTRACT: This paper investigates the enunciative responsibility in academic texts written by beginning writers, aiming specifically to describe and to interpret enunciative positions of first speaker/enunciator (S1/E1) at the time of imputation of points of view (PoV) to second enunciators (E2). Theoretically, this paper is based on postulates of Textual Analysis of Discourses (TAD), according to Adam (2011), in articulation with studies of Guentchéva (1994), observations of Authier-Revuz (1998, 2004) about enunciative heterogeneity, among other authors. In the texts analyzed, it was more recurrent the expression of favorable positions by S1/E1 in situations of retaken, reformulations and comments that confirm and validate the speaking of the other. The results show that the beginning researcher establishes a kind of dialogue with unrelated PoV directed to the construction of a bond of shared responsibilization.

Este trabalho apresenta-se como um recorte da pesquisa de doutorado (BERNARDINO, 2015), desenvolvida no Programa de Pós-graduaçăo em Estudos da Linguagem (SIGLA/IES), com o apoio da CAPES e mediado pelo Programa Observatório da Educaçáo (OBEDUC), sob a orientaçăo da Profa. Dra. Maria das Graças Soares Rodrigues. A análise foi originalmente socializada na forma de Comunicaçấo Oral (mas náo publicada em sua versâo escrita completa), por ocasiáo do III Congresso Internacional Linguagem e Interaçấo, que ocorreu em Sáo Leopoldo/RS, de 17 a 19 de junho de 2015.

2 Docente da Universidade do Estado do Rio Grande do Norte (UERN), atuando na área de linguística no Departamento de Letras Estrangeiras (DLE) do Campus de Pau dos Ferros, RN. Doutora em Estudos da Linguagem pela Universidade Federal do Rio Grande do Norte (UFRN), na área de concentraçáo em Linguística Aplicada.E-mail: 〈rosealves_23@yahoo.com.br〉. 
KEYWORDS: enunciative responsibility; scientific article; beginning researcher; imputation; enunciative position.

\section{PALAVRAS INICIAIS}

Quando consideramos o plano enunciativo da análise textual, ou nível 7, no qual se situa a responsabilidade enunciativa e a coesâo polifônica, tal como se concebe na Análise Textual dos Discursos (ATD) proposta por Adam (2011), um dos aspectos que nos tem chamado a atençáo diz respeito aos laços de (nâo) responsabilizaçăo (RABATEL, 2013) construídos pelo primeiro locutor-enunciador (L1/E1) ao lidar com pontos de vista (PdV) de outrem. Algumas afirmaçóes teóricas advindas da ATD e do campo enunciativo nos tem permitido, entăo, refletir sobre o que pensa L1/E1 ao responsabilizar outro locutor-enunciador (e2) pelo conteúdo proposicional de um PdV, entre as quais destacamos:

a) "Os enunciados podem, assim, năo ser assumidos pelo locutor-narrador." (ADAM, 2011, p. 115).

b) um PDV corresponde a um conteúdo proposicional remetendo a um enunciador ao qual o locutor 'se assimila' ou, ao contrário, se distancia. ${ }^{3}$ (RABATEL, 2005, p. 59, traduçăo nossa).

c) Quando L1/E1 reconhece o ponto de vista de e2, isso significa que ele nâo o rejeita, ao mesmo tempo em que nâo aceita: ele apenas confirma o fato em si significativo de integrá-lo no discurso. É somente em uma etapa posterior [...] que L1/E1 se posicionará em relaçâo a esse PDV imputado, rejeitando ou o aceitando como seu ${ }^{4}$ (RABATEL, 2009, p. 76, traduçăo nossa).

Trata-se, pois, de afirmaçôes que colocam em evidência a possibilidade de engajamento ou de distanciamento do L1/E1 em relaçăo a um PdV imputado a outrem. No texto acadêmico-científico, esse procedimento da imputaçâo mostra-se indispensável toda vez que o autor mobiliza um discurso que năo é seu: uma palavra, uma ideia, enfim, um ponto de vista, sendo isso em funçáo da necessidade de demarcar um lugar teórico e de fundamentar e conferir autoridade a seu próprio dizer. Mas ocorre que, justamente pela necessidade de instaurar uma voz própria, o autor precisa tomar posiçóes enunciativas no discurso e năo apenas reproduzir e assumir PdV alheios.

Pensando nessas questōes, este trabalho investiga a responsabilidade enunciativa no texto acadêmico-científico, propondo especificamente descrever e interpretar os posicionamentos enunciativos do primeiro locutor-enunciador quando da imputaçáo de pontos de vista a enunciadores segundos. Tendo em vista os contextos de imputaçăo de PdV, nos termos como propóe Rabatel (2009), buscamos verificar como se constroem os laços de (nâo) responsabilizaçâo em relaçáo às vozes alheias citadas no gênero artigo científico, o que nos permite visualizar a dimensăo interacional dessas vozes na escrita do pesquisador iniciante.

3 Un PDV correspond à un contenu propositionnel renvoyant à un énonciateur auquel le locuteur « s'assimile » ou au contraire dont il se distancie.

$4 \quad$ Lorsque L1 /E1 prend en compte un point de vue de e2, cela signifie qu'il ne le rejette pas, sans pour autant l'accepter: il n'entérine que le fait, en soi déjà significatif, de l'intégrer dans son discours. C'est seulement dans une étape ultérieure [...] que L1/E1 se positionnera par rapport à ce PDV imputé, en le rejetant ou le faisant sien. 
Por se tratar de uma pesquisa que se debruça sobre a produçăo do texto acadêmicocientífico, propomos aqui um olhar sobre o fenômeno da responsabilidade enunciativa de maneira articulada com a noçăo de autoria, em sintonia com as postulaçôes teóricas de Rabatel (2010), pesquisador que retoma as reflexóes foucaultianas sobre o que é ser autor (FOUCAULT, 2012). Desse modo, impōe-se como pressuposto teórico assumido na análise dos dados a compreensâo de que ser autor vai além da assunçăo da responsabilidade pelos PdV alheios, pois culmina na contribuiçăo pessoal, na gestăo das vozes citadas no texto, na singularidade do PdV, mesmo diante de um conjunto de trabalhos anteriores. No texto acadêmico-científico, sobretudo quando o autor/ pesquisador ainda é inexperiente, isso năo se faz sem dificuldades, uma vez que ele precisa saber dialogar com um número indefinido de fontes, de outros discursos (é o saber citar, explicar, estabelecer relaçōes, comentar, posicionar-se etc.) e năo incorrer no "apagamento" da voz autoral em meio a esse coletivo de vozes alheias. Daí a relevância de compreendermos como se dá e qual é, afinal, o estatuto dessas vozes alheias na construçăo interacional da voz própria do pesquisador em processo de formaçăo.

O corpus constitui-se de oito artigos científicos produzidos por pesquisadores iniciantes e publicados em uma revista especializada da área de Letras, intitulada Diálogo das Letras, criada em 2012 pelo Grupo de Pesquisa em Produçáo e Ensino de Texto (GPET), vinculado ao Departamento de Letras Estrangeiras (DLE), do Campus Avançado "Profa. Maria Elisa de Albuquerque Maia" (CAMEAM), da Universidade do Estado do Rio Grande do Norte (UERN), em Pau dos Ferros, RN.

A coleta dos artigos considerou os três primeiros números da revista (vol. 1, n1 e n2 de 2012; vol. 2, n1 de 2013), por conterem uma seçăo específica destinada para alunos de graduaçăo. ${ }^{5}$ No contexto específico da nossa pesquisa, o termo iniciante refere-se, pois, a estudantes situados nesse nível de formaçăo acadêmica, cujo trabalho năo apresenta coautoria com outro tipo de pesquisador (mestre ou doutor). Os artigos situam-se num contexto de produçâo e de circulaçâo que requer a adequaçăo a um conjunto de normas previamente estabelecidas. Como critérios avaliativos, exige-se: "ineditismo, coerência com a temática do número da revista, consistência teórico-metodológica, relevância para a área, pertinência da bibliografia, correçăo textual e gramatical e adequaçấo a normas de apresentação de trabalhos acadêmicos". (Cf. página eletrônica da revista).

Teoricamente, seguimos os postulados da ATD, com base em Adam (2011), o estudo de Guentchéva (1994), as observaçōes de Authier-Revuz (1998, 2004) sobre a heterogeneidade enunciativa, tendo em conta, também, a concepçấo dialógica dos enunciados, conforme Bakhtin e o Círculo (2002, 2006). Ao nos filiarmos a este quadro teórico, elegemos três categorias de análise para dar conta do estudo da responsabilidade enunciativa, quais sejam: os diferentes tipos de representaçăo de fala, as indicaçóes de quadros mediadores (ou mediativo) e os fenômenos de modalizaçăo autonímica, justamente por serem elas reveladoras da inscriçăo do outro no fio textual. Até porque, considerando a natureza do gênero, sabemos que o artigo científico "sofre" os efeitos

Em 2014, um ano após a coleta do corpus da pesquisa de doutorado à qual se filia este trabalho, a revista realizou algumas alteraçóes. No "foco" e "escopo", passa a "expressar o desejo de promover a disseminaçăo da produçâo científica, preferencialmente, de estudantes de pós-graduaçấo stricto sensu, de professores universitários e de pesquisadores com título de mestre ou doutor". (cf. página eletrônica da revista). 
de regulaçăo do campo ou esfera a que está vinculado, devendo, pois, submeter-se à denominada "impressâo de objetividade". De certo, isto faz com que o pesquisador, inconscientemente ou náo, empregue: a) no citar das fontes, os diferentes tipos de representaçăo de fala; b) no tentar o distanciamento, os quadros mediadores; e c) no esforçar-se para năo revelar sua subjetividade de pesquisador, cai na "armadilha" da năo transparência da linguagem, pelos fenômenos da modalizaçâo autonímica. Em outras palavras, o artigo científico, como uma forma de expressăo da linguagem em sentido amplo - assumida neste trabalho como dialógica e heterogênea - está propício à manifestaçấo de pontos de vista que o pesquisador pode (năo) assumir, atribuir a outrem (imputar), posicionar-se de modo favorável ou năo, debruçar-se sobre eles reflexivamente, mostrar-se distanciado etc.

Além de colaborar para a divulgaçâo das pesquisas no âmbito da ATD e para potencializar sua capacidade de análise da produçấo co(n)textual de sentidos nas mais diferentes esferas da comunicaçăo humana, almejamos particularmente promover o debate sobre o manejo de estratégias textuais/discursivas que indicam a responsabilidade enunciativa no texto acadêmico-científico, em especial quando produzido por pesquisador situado na posiçăo de iniciante.

Após estas palavras introdutórias, este texto apresenta duas seçōes principais, sendo uma dedicada a discutir sobre a noçăo responsabilidade enunciativa como uma entre as categorias que compóem o plano da análise textual, conforme Adam (2011), e a outra destinada à análise dos dados, que dá conta de um dos aspectos focalizados em nossa pesquisa de doutorado (BERNARDINO, 2015), consistindo em verificar como os pesquisadores iniciantes se posicionam em relaçăo a pontos de vista alheios.

\section{CONSIDERAÇÕES TEÓRICAS SOBRE A RESPONSABILIDADE ENUNCIATIVA}

A responsabilidade enunciativa consiste em uma das categorias da ATD, discutidas por Adam (2011) em dois momentos de sua obra (tópico 3.4, do capítulo 2; tópico 5.2, do capítulo 3). Na obra, essa noçăo é correlata a ponto de vista e refere-se ao fato de que o locutor narrador pode assumir, ou atribuir a outro, o conteúdo de seus enunciados. Certas unidades da língua permitem assinalar a porçăo dos discursos que (nâo) é assumida pelo locutor narrador. É isso o que postula Adam (2011, p. 117) ao afirmar que "o grau de responsabilidade enunciativa de uma proposiçấo é suscetível de ser marcado por um número de unidades da língua".

Passeggi et al. (2010, p. 299) entendem que este fenômeno "consiste na assunçăo por determinadas entidades ou instâncias do conteúdo do que é enunciado, ou na atribuiçâo de alguns enunciados ou PdV a certas instâncias" (grifos nossos). Semelhante a Adam (2011), eles compreendem que a responsabilidade enunciativa é inseparável do PdV. Os dois termos em negrito destacam a articulaçăo que fazemos entre as acepçóes de Adam e Rabatel, uma vez que remetem, respectivamente, à responsabilizaçăo e à imputaçăo. Além disso, ambas as acepçôes se inserem na perspectiva dialógica da linguagem, revelando o desdobramento polifônico do enunciado. Para o tratamento da responsabilidade enunciativa neste trabalho, essa articulaçáo será estabelecida.

Rabatel (2009) concebe a responsabilidade enunciativa (ou responsabilizaçâo) referindo-se aos casos em que L1/E1 assume por conta própria os conteúdos proposicionais 
do PdV6 que ele julga verdadeiros. Associado a esse conceito, o autor postula a noçáo de imputação, para as ocorrências em que L1/E1 atribui os conteúdos proposicionais a outro enunciador, ou seja, a um e2. Além disso, defende a hipótese de uma quase-reponsabilizaçâo7, referindo-se à imputaçăo do PdV a um e2, com posicionamento de L1/E1. Este marca o seu engajamento a partir de um acordo favorável em relaçăo ao PdV imputado. Rabatel (2009, p. 73, traduçấo nossa) afirma: é esta quase PEC, imputada a e2, que permite em seguida que L1/E1 se posicione em relaçăo à posiçăo enunciativa de e2.8 Logo, duas questóes emergem dessa definiçăo: qual é o PdV de L1/E1? O que ele pensa sobre o PdV quando o imputa a outrem? Daí se conclui que os enunciadores segundos também estăo envolvidos com a responsabilidade enunciativa, via imputaçăo.

É exatamente pela ideia de uma responsabilidade enunciativa pressuposta que se pode admitir que L1/E1 imputa um engajamento pelo conteúdo do PdV a um e2, mesmo que ele náo tenha dito palavra alguma. Rabatel (2009) reconhece a complexidade desse tipo de imputaçaáo, porque nem todas as línguas (o francês, por exemplo) dispóem de marcas morfológicas para indicá-la. $\mathrm{O}$ apoio no dialogismo bakhtiniano constitutivo ao discurso ajuda a resolver tal dificuldade, pelo fato de aceitar fontes externas e anteriores ao dizer de L1/E1. Assim, quando um L1/E1 imputa a responsabilidade a um e2, mesmo quando este năo disse nada, as seguintes situaçōes podem estar em causa:

a) Provas anteriores à fala: L1/E1 apoia-se em algo que e2 lhe teria dito/afirmado/ admitido em momento anterior;

b) Relatos de terceiros: L1/E1 apoia-se em algo que ouviu dizer/afirmar, por terceiros, a respeito de e2;

c) Inferências: L1/E1 levantou inferências a partir de um comportamento anterior de e2. Nesse caso, L1/E1 apoia-se em algo que ele mesmo verificou a respeito de e2.

De acordo com Rabatel (2009), as variantes a, b e c apoiam o conteúdo proposicional de um enunciado imputado a e2 por meio de "fontes evidenciais". O conceito de fonte refere-se a uma origem externa ao dizer de L1/E1 e que o apoia nesses casos de imputaçăo. Nas três situaçóes, as fontes se responsabilizam pelo PdV em um tempo e momento anteriores à enunciaçăo, supondo, pois, que um e2 deve ter falado antes.

Retomamos mais uma vez as palavras de Rabatel (2009, p. 74, traduçăo nossa), para dizermos que a imputaçâo é, portanto, uma PEC com responsabilidade limitada, pois foi construída pelo primeiro locutor, atribuído por ele a um segundo locutor/enunciador que pode sempre alegar que nâo é o responsável pelo PDV que L1/E1 lhe atribuiu indevidamente ${ }^{9}$. No ato da imputaçáo de um PdV, está o fato de L1/E1 poder se posicionar

Rabatel (2009) utiliza a abreviaçăo de ponto de vista com letras maiúsculas (PDV), já Adam (2011) emprega PdV. Neste trabalho, usamos a abreviaçăo deste autor, mas sem nos distanciarmos das postulaçôes de Rabatel.

7 Rabatel usa a abreviaçăo PEC, para responsabilidade enunciativa, e Quasi PEC, para quaseresponsabilizaçăo. Teríamos o equivalente RE e Quase-RE em português.

$8 \quad$ C'est cette quasi $P E C$, imputée à e2, qui permet ensuite à L1/E1 de se positionner par rapport à la position énonciative de e2.

$9 \quad$ L'imputation est donc une PEC à responsabilité limitée, parce que constuite par le locuteur premier, attribuée par lui à un locuteur/énonciateur second qui peut toujours alléguer qu'il n'est pas reponsable d'un PDV que L1/E1 lui a imputé à tort. (No texto original, o autor empregou o termo "responsabilité limitée" em itálico). 
favoravelmente em relaçăo ao conteúdo proposicional, ou mostrar-se em desacordo, ou simplesmente năo se manifestar. Se L1/E1 concorda com o PdV atribuído por ele a e2, tem-se aí um compartilhamento, conduzindo-nos a crer que o PdV parece ser o mesmo para ambos. Já o desacordo demarca a refutaçăo do PdV alheio, a năo assunçâo pelo seu conteúdo proposicional; por sua vez, a neutralidade diz respeito à possibilidade de um afastamento do enunciador, ainda que provisório. O trabalho de Rabatel (2009) permite, entâo, depreender pelo menos três possibilidades de posicionamento de L1/ E1, conforme o quadro abaixo.

\section{Quadro 1: Posicionamentos do primeiro locutor-enunciador (L1/E1)}

\begin{tabular}{c|c}
\hline 1 Acordo total ou parcial & $\begin{array}{r}\text { Compartilhamento (operações de focalização, de enriquecimento, de confirmação } \\
\text { e de retificação do PDV imputado a e2). }\end{array}$ \\
\hline 2 Neutralidade & Afastamento (operações de focalização) \\
\hline 3 Desacordo & Negação do PDV imputado a e2. \\
\hline
\end{tabular}

Fonte: elaboração própria

Como se vê, estăo em destaque as diferentes atitudes de L1/E1 em relaçăo ao PdV imputado a outro enunciador. Como uma espécie de continuum, L1/E1 pode manifestar-se de modo favorável ao que disse e2, ou apenas parcialmente. De um lado, pode haver, da parte de L1/E1, compartilhamento do PdV com e2, ou seja, mesmo nâo se responsabilizando inicialmente pelo PdV, L1/E1 pode tomá-lo como seu, realizando sobre ele diversas operaçōes: focalizar, enriquecer, confirmar e retificar. De outro lado, o desacordo revela a năo assunçăo da responsabilidade enunciativa por L1/E1, tendo em vista a atuaçăo da negaçăo, fazendo com que e2 assuma sozinho o PdV. Já a neutralidade, posicionada de forma intermediária, manifesta o afastamento provisório de L1/E1, que, por alguma razăo, năo deseja revelar se é favorável ou năo ao PdV. Rabatel (2009) diz que essa neutralidade é teoricamente possível, mas năo se sustenta por muito tempo, pois, em algum momento, será cobrado de L1/E1 tomar alguma posiçăo.

É preciso notar que, nas três possibilidades mostradas no quadro anterior, a fonte enunciativa do PdV recai sobre e2, independentemente da posiçăo favorável ou năo de L1/E1, uma vez que se trata de contextos de imputaçăo. No quadro 2, a seguir, podemos verificar como se dâo os contextos de responsabilizaçăo no ato da imputaçăo (cf. RABATEL, 2009, p. 75).

\section{Quadro 2: Contextos de responsabilização no ato da imputação de PDV a e2}

\begin{tabular}{|c|c|}
\hline 1 Reconhecimento & $\begin{array}{c}\text { L1/E1 imputa porque reconhece que o PDV pertence a outros, portanto não é } \\
\text { seu. }\end{array}$ \\
\hline 2 Engajamento e desengajamento & $\begin{array}{l}\text { Em etapa posterior, L1/E1 pode manifestar-se em relação ao PDV imputado } \\
\text { (que foi reconhecido como alheio), rejeitando ou aceitando como seu. }\end{array}$ \\
\hline $\begin{array}{c}3 \text { Força ilocutária, expressão de } \\
\text { modalidades }\end{array}$ & $\begin{array}{l}\text { A posição em relação ao PDV pode se dar em graus variados, de modo que } \\
\text { L1/E1 pode ser muito afirmativo, pode modalizar seu próprio PDV (afastando- } \\
\text { se) ou ocultá-lo, escondendo-se por trás de uma opinião geral. }\end{array}$ \\
\hline
\end{tabular}

Fonte: elaboração própria 
Desta vez, colocamos em evidência as relaçóes da responsabilizaçâo com outras três noçôes: o reconhecimento, o engajamento e a força ilocutária. Com base em Rabatel (2009), somos levados a compreender que: 1) todo reconhecimento (de que o PdV é alheio) implica uma imputaçâo prévia da reponsabilidade enunciativa; 2) por mais objetivo e impessoal que seja, L1/E1 manifesta uma posiçăo, revela algum grau de engajamento; e 3) a força ilocutária baixa, o afastamento ou a expressâo de modalidades năo atenuam o fenômeno da responsabilizaçâo por L1/E1. Tudo isso se relaciona com o manejo de estratégias textuais/discursivas, com as negociaçóes de L1/E1, que ora pode se responsabilizar por conta própria pelo conteúdo proposicional do PdV, ora pode imputá-lo a e2, mas sem que isso o exima de tomar uma posiçăo no discurso.

Feitas essas consideraçôes conceituais, destacamos que entre as categorias e marcas linguísticas que indicam a responsabilidade enunciativa, nos centramos especificamente em três, conforme pontuamos a seguir.

i) Os diferentes tipos de representaçăo da fala - esta categoria diz respeito ao "falar pelos outros", como uma das formas de expressāo do dialogismo (AUTHIER-REVUZ, 1998, p. 122). Entre suas formas de materializaçăo, citemos o discurso direto (DD), o discurso direto livre (DDL), o discurso indireto (DI), o discurso narrativizado (DN) e o discurso indireto livre (DIL), conforme Adam (2011). Ao utilizarmos esta categoria para estudo da responsabilidade enunciativa, retomamos as observaçóes teóricas de Authier-Revuz (2004) no campo do "discurso relatado" ou dos "modos de representaçâo no discurso de um discurso outro". Tais observaçôes mostram-se ancoradas no princípio da heterogeneidade constitutiva, que por sua vez se apoia no dialogismo bakhtiniano e na concepçăo lacaniana, relida de Freud, acerca do "descentramento do sujeito" - uma visăo que assume como constitutiva e permanente a presença do outro (outros discursos) e do Outro (discursos do inconsciente) no discurso - e também na noçăo de interdiscurso mencionada em estudos pêcheuxtianos.

ii) As indicaçóes de quadros mediadores - correspondem teoricamente ao que Authier-Revuz $(2008,2004)$ chama de modalizaçăo do dizer como discurso segundo ou simplesmente modalizaçâo por discurso segundo (MDS), quando esta autora trata das formas de representaçấo do discurso do outro, especificamente das que sâo introduzidas com marcadores como Segundo, De acordo com, Conforme e Para. Em Guentchéva (1994, p. 08, traduçăo nossa), o mediativo (MED) recobre um conjunto de procedimentos gramaticais existentes em numerosas línguas que permitem ao enunciador significar os diferentes graus de distância que ele toma com respeito às situaçōes descritas, já que ele as distinguiu de maneira mediada ${ }^{10}$. A autora diz que o enunciador estabelece uma espécie de continuum para marcar seu engajamento ou distanciamento em relaçăo às situaçóes descritas, sem precisar se expressar quanto à verdade ou falsidade do conteúdo proposicional do enunciado.

iii) Os fenômenos de modalizaçăo autonímica - Conforme Adam (2011), a base conceitual desta categoria săo os trabalhos de "Authier-Revuz (1998, 1994, 1995)", que se fundamentam no princípio da "metadiscursividade" como propriedade da linguagem humana e em balizagens teóricas que destituem do sujeito o domínio

10 [...] qui permettent à l'énonciateur de signifier les différents degrés de distance qu'il prend à l'égard des situations décrites puisqu'il les a perçues de façon médiate. 
sobre seu próprio dizer. Ele retoma esses trabalhos e os segue, denominando os fenômenos de modalizaçáo autonímica como: "todo enunciado metaenunciativo que, num debruçar-se reflexivo do dito sobre o dizer, manifesta a năo-transparência e a năo-evidência das palavras." (ADAM, 2011, p. 120). Tais fenômenos se inscrevem no campo da alteridade discursiva e podem encontrar nas aspas e itálico a indicaçăo dessa alteridade. Neste caso, entende-se a enunciaçăo que nâo é somente realizaçăo, mas comentário reflexivo de si mesma, atestando decisivamente a relaçăo do sujeito com a linguagem, cuja manifestaçăo se dá a partir dos seguintes pontos:

1) formas explicitamente metaenunciativas completas, comportando eu digo $X^{\prime}$;

2) formas explicitamente metaenunciativas que indicam um eu digo $X^{\prime}$, subordinadas e sintagmas circunstanciais, oposiçōes;

3) formas explicitamente metalinguísticas, com um autônimo $X^{\prime}$ ou $Y^{\prime}$

4) formas sem elemento autônimo, ou sem elemento metalinguístico unívoco;

5) Sinais tipográficos (aspas, itálico);

6) formas puramente interpretativas que abrem para a heterogeneidade constitutiva (por exemplo, as alusóes).

De acordo com as consideraçóes de Authier-Revuz (1998), o dizer é afetado por quatro campos de náo coincidência, e isso mostra, como afirmou Adam (2011), que as palavras podem (nâo) ser assumidas pelo locutor-enunciador. Assim, a responsabilidade enunciativa pode ser, de algum modo, partilhada entre os enunciadores ("digamos $\mathrm{X}^{\prime \prime}$ ) ou, ao contrário, atribuída a um ou ao outro enunciador - "as palavras que digo nâo săo as suas"; "as palavras que digo săo as suas, năo as minhas" - (1) é a năo coincidência interlocutiva. As fronteiras entre o dizer de si e do dizer outro sâo assinaladas na superfície da "interdiscursividade representada", o que atesta que as palavras podem ser retomadas do outro, apropriadas de um outro lugar, de outra época, de uma teoria, de uma pessoa etc., associadas ao discurso, advindas de outra língua, outra regiâo, época, registro, socioleto, discurso teórico, posiçâo política etc. - (2) é a nâo coincidência do discurso consigo mesmo.

A nomeaçăo do real faz despontar a separaçăo palavra/coisa, revela "a falta de captura do objeto pela letra", o enunciador procura as palavras que o realizem na nomeaçăo, ou que se adequem a ela, ou mesmo se dá conta da própria falta da nomeaçăo - (3) é a năo coincidência entre as palavras e as coisas. Por fim, como que controlando o sentido das palavras, jogando com elas, o enunciador cai no equívoco, pelo distanciamento entre a palavra e seu sentido - (4) é a năo coincidência das palavras consigo mesmas.

Em (1) e (2), as palavras podem ser assumidas ou atribuídas a outrem; já em (3) e (4), elas estấo sob o "controle" do enunciador, na tentativa de nomear o real e de atribuir os sentidos de suas palavras. Os discursos e gêneros em que se realizam esses pontos de nâo coincidência săo variados. Authier-Revuz (1998) cita os diálogos diversos, o texto polêmico, o gênero de divulgaçáo científica (para caso 1); discursos diversos sobre o passado, romances regionalistas, textos teóricos, textos políticos, entre outros (para o caso 2); entrevistas, textos literários (caso 3); discursos do campo midiático, teórico, literário (caso 4). 


\section{DESCRIÇÃO DOS POSICIONAMENTOS DO PRIMEIRO LOCUTOR- ENUNCIADOR NOS CONTEXTOS DE IMPUTAÇÃO DE PDV A E2}

Como dissemos no aporte teórico deste trabalho, o locutor-enunciador pode (năo) assumir o conteúdo proposicional dos PdV proferidos no texto (ADAM, 2011). Afirmamos, também, que L1/E1 pode assimilar-se ao PdV imputado (concordar/engajar-se), ou se distanciar (discordar/refutar), ou ainda năo se manifestar, expressando sua neutralidade (RABATEL, 2009). Dito de outra maneira, é possível sinalizar no texto os diferentes graus de engajamento ou de distanciamento em relaçâo às situaçôes descritas (GUENTCHÉVA, 1994). Os excertos dispostos nesta seçâo evidenciam o modo como o pesquisador iniciante se posiciona em relaçăo a pontos de vista alheios no gênero artigo científico.

Por questôes didático-metodológicas, os artigos científicos săo apresentados por excertos, mas sem perder de vista o seu contexto de produçăo. Cada artigo está devidamente codificado, garantindo a preservaçăo de identidade dos autores. Os excertos foram dispostos em sequência (de 01 a 13), sem ter sofrido qualquer tipo de alteraçâo em relaçâo ao texto original. A codificaçăo entre parênteses (Ac01, 2011, p. 02) identifica o número de ordem (de 01 a 08) do artigo científico (Ac), acrescido do ano de publicaçăo do texto e da página de onde foi retirado o recorte. Para destacar as marcas linguísticas de (nâo) assunçâo da responsabilidade enunciativa, usamos dois tipos de recursos tipográficos: o negrito, para visualizar as referidas marcas, e o sublinhado, nos casos em que precisamos diferenciar do negrito já posto no texto original. Por fim, inserimos um realce (pano de fundo branco, em tom mais escuro, $5 \%)$ apenas como recurso para destacar os recortes dos artigos científicos analisados em relaçấo ao corpo deste texto.

\section{A responsabilizaçăo compartilhada - posiçăo de acor- do no ato da imputaçăo}

Aqui, sâo apresentadas as situaçóes que chamamos de PdV alheios com responsabilizaçấo compartilhada. Elas se localizam em diferentes pontos dos artigos científicos, com mais frequência na seçăo teórica, onde um ou mais PdV foram imputados a outros enunciadores e seguidos ou antecedidos por um posicionamento enunciativo favorável de L1/E1 (total ou parcialmente e explícita ou implicitamente), em relaçáo ao conteúdo proposicional abordado. Em cada artigo, identificamos e descrevemos as marcas linguísticas que assinalam o modo como se deu a imputaçâo (por diferentes tipos de representaçấo de fala, por indicaçôes de quadros mediadores e por pontos de năo-coincidência do dizer), conforme demonstram os excertos a seguir.

(01)

Às expressōes referenciais se atribui um caráter muito importante para o processamento textual que, dentro da concepçâo de linguagem como atividade interacional, deve ser entendido, segundo postula Koch (2001), como uma atividade que envolve tanto elementos linguísticos como sociocognitivos. Para ela, o texto, no interior dessa abordagem, é também considerado como um conjunto de "pistas" 
que săo formadas por elementos linguísticos de diversos tipos. Estes săo colocados à disposiçấo dos usuários da língua, durante uma atividade discursiva, de modo a facilitar ao falante năo só a construçăo reconstruçăo de sentidos, mas também na interaçăo como prática sociocultural. No curso dessa atividade textual, os sujeitos mobilizam conhecimentos linguístico, enciclopédico e interacional, que os tem depositado na memória através de um conjunto de estratégias de processamento de caráter sociocognitivo e textual.

(Ac01, 2012, pp. 221-222)

Neste trecho do Ac01, as expressōes "Segundo postula Koch (2001)" e "Para ela" săo marcas linguísticas expressivas do fenômeno que Guentchéva (1994) denomina de mediativo, Authier-Revuz $(2008,2004)$ de modalizaçăo em ou por discurso segundo (MDS) - sobre o conteúdo - e que Adam (2011), fundamentado em ambas as autoras, o apresenta como indicaçóes de quadros mediadores, entre a lista de categorias que manifestam a RE. Em nossa análise, usamos a abreviaçáo MED (de mediativo), mas sem fazer distinçăo teórica entre as três terminologias, até porque nos respaldamos teoricamente nesses trabalhos mencionados.

As aspas no termo "pistas" săo marcas que delimitam um fenômeno de modalizaçăo autonímica, demarcando um tipo de outro no fio textual do discurso, no âmbito da năocoincidência do discurso consigo mesmo. No excerto em destaque, elas sugerem que essa palavra pertence a abordagem do texto dentro de uma "concepçáo de linguagem como atividade interacional".

Entre as marcas linguísticas destacadas no excerto (01), duas delas permitem-nos observar náo o um falando do outro (o que ocorreria no DD, no DI e nos demais tipos de representaçăo de fala), mas o um falando segundo o outro (AUTHIER-REVUZ, 2008). No exemplo, L1/E1 enuncia sobre as expressōes referenciais "segundo" a postulaçâo de Koch (2001), no que se refere à importância de tais expressôes "para o processamento textual" e, ainda mais, sobre o modo como este processamento "deve ser entendido" (no sentido de envolver elementos linguísticos e sociocognitivos ao mesmo tempo), "dentro da concepçáo de linguagem como atividade interacional". Do mesmo modo, ao dizer "para ela", L1/E1 atribui a Koch todo o PdV que discorre sobre o texto, como ele é considerado dentro da abordagem interacional da linguagem.

No âmbito discursivo, um dos efeitos de sentido de se falar segundo o outro, é que esse outro afeta diretamente o dizer, constituindo-se como a fonte e o responsável pelo PdV. Como consequência, a verdade do conteúdo proposicional do PdV recai totalmente sobre e2, isentando L1/E1 de se comprometer, uma vez que este somente se encarregaria da reformulaçâo das palavras. Mas a questâo é que, no artigo científico (e certamente em muitos outros gêneros do discurso), o fato de o PdV ser fundado na fala de outrem nâo desobriga L1/E1 de possíveis contestaçôes, de "nuances de dúvida, ironia, indignaçâo e rejeiçâo", retomando aqui as palavras de Neves (2012, p. 78), sobretudo se a reformulaçăo năo se fizer equivalente ao ato enunciativo anterior, isto é, ao que e2 teria dito, de fato. Sobre isso, năo constitui nosso propósito duvidar da fidelidade da interpretaçăo de L1/E1 em relaçáo ao conteúdo das palavras proferidas por Koch (2001). Interessa perceber que, em (01), o contexto da imputaçấo exibe a 
responsabilizaçăo compartilhada: o pesquisador iniciante relata fatos admitidos pela teoria adotada no Ac01, mostrando-se inteiramente favorável em relaçâo ao caráter importante das expressôes referenciais para o processamento textual e a como este deve ser entendido dentro da concepçâo interacional da linguagem.

Essas características peculiares dos gêneros permitem abordar aspectos da textualidade tais como: coerência e coesâo, impessoalidade técnicas de argumentaçáo e outros aspectos pertinentes ao gênero em questăo. O revisor precisa estar familiarizado com os diversos gêneros produzidos. Vale aqui correlacionar os gêneros com a questăo do imaginário, pois, no entender de Silva (2006, pp. 13-14),

a construçâo do imaginário individual se dá, essencialmente por identificaçâo (reconhecimento de si no outro), apropriaçâo (desejo de ter o outro em si) e distorçăo (reelaboraçâo do outro para si). O imaginário social estrutura-se principalmente por contágio: aceitaçăo do modelo do outro (lógica tribal), disseminaçăo (igualdade na diferença) e imitaçáo (distinçáo do todo por difusâo de uma parte). No imaginário há sempre desvio. No desvio há potencialidade de canonizaçăo. O imaginário explica o 'eu' (parte) no 'outro' (todo). Mostra como se permanece individual no grupo e grupal na cultura.

Esse dizer nos leva a entender o fato de que se hoje se conhece os gêneros textuais existentes é porque houve uma identificaçăo, uma apropriaçăo e também uma distorçăo, o que resultou em aceitaçâo pelo público, o qual disseminou e imitou o que já existia e assim foi sendo adaptado. Faz-se necessário a esses profissionais conhecer as fórmulas de cada gênero para assim fazer uso de seu conhecimento de mundo ao revisá-los ou escrevê-los. Squarisi e Salvador (2005, p.54) destacam que "conhecer de antemáo o gênero que se vai produzir é meio caminho para escrever bem". Portanto, é indispensável que o profissional de Letras conheça os gêneros, as regras gramaticais que regem a língua culta, bem como que tenha domínio no uso sobre esses conhecimentos. Além disso, os redatores e revisores devem estar atentos às mudanças, sejam elas no âmbito social, cultural, histórico ou científico. $[\ldots]$.

(Ac02, 2012, pp. 234-235)

Neste ponto do Ac02, L1/E1 demarca a exterioridade que atravessa seu PdV pela indicaçăo da fronteira entre si e o outro, ou melhor, pela explicitaçâo do tipo de outro, que é um autor da área. Para validar seu PdV (o da correlaçâo entre os gêneros e o imaginário), L1/E1 busca justificá-lo a partir do "entender de Silva (2006, p. 13-14)" em relaçăo às diferentes formas pelas quais se constrói e se estrutura o imaginário social.

Temos, neste caso, a fixaçăo do sentido, direcionado para o âmbito do "entender de Silva (2010, p. 13-14)". Isso fica ainda mais claro nas palavras seguintes, quando L1/E1 assume que o "dizer" de Silva "nos leva a entender o fato de que se hoje se conhece os gêneros textuais existentes é porque houve uma identificaçăo, uma apropriaçâo e também uma distorçấo, o que resultou em aceitaçăo pelo público, o qual disseminou e imitou o que já existia e assim foi sendo adaptado". Com isso, L1/E1 desautoriza qualquer 
ambiguidade: fazer o tipo de correlaçăo sugerida entre os gêneros e o imaginário social é válido na medida em que levamos em conta o entender daquele autor.

O recurso do itálico na palavra "fórmulas" também atua como especificador do tipo de outro, no âmbito da năo-coincidência do discurso consigo mesmo. O distanciamento enunciativo por parte de L1/E1 em relaçấo a este termo é provisório, uma vez que o vemos integrado como palavra-chave do PdV de L1/E1 sobre a importância de o profissional de revisăo de textos conhecer e dominar os gêneros textuais.

No excerto, há ainda o DD com "que" como marca linguística que sinaliza a imputaçâo do PdV a e2. É o que ocorre na seguinte passagem: Squarisi e Salvador (2005, p.54) destacam que "conhecer de antemâo o gênero que se vai produzir é meio caminho para escrever bem". As palavras que comentam este PdV evidenciam o posicionamento favorável de L1/E1 no tocante à importância de o revisor de textos conhecer os gêneros.

\section{(03)}

\section{Aprendizagem de língua estrangeira}

Segundo O'Malley et al (1985), a língua materna no contexto da aprendizagem de língua estrangeira funciona como uma estratégia de processamento; o aprendiz que ainda náo domina com fluência a língua estrangeira ou que náo está familiarizado com certas estruturas gramaticais, se apoia na língua materna. Em outras palavras, quando o aluno se vê diante de uma situaçăo comunicativa em que náo está dotado de recursos linguísticos suficientes, acaba buscando recursos linguísticos oriundos da sua própria língua materna; isso resulta em uma combinaçăo de estruturas gramaticais.

O processamento gramatical, nessa perspectiva, está vinculado às estratégias de aprendizagem. Mas o que seria uma estratégia de aprendizagem?

Para esclarecer esse questionamento, assumiremos o posicionamento teórico de Oxford (1990 apud VILAÇA, 2010, p. 211):

Estratégias de aprendizagem sáo passos dados pelos estudantes para melhorar sua aprendizagem. As estratégias sâo especialmente importantes na aprendizagem de línguas porque elas săo ferramentas para um envolvimento ativo e autodirigido, o que é essencial para o desenvolvimento da competência comunicativa. Estratégias de aprendizagem de línguas apropriadas resultam em proficiência aperfeiçoada e maior autoconfiança.

Nesse sentido, a combinaçáo das gramáticas provenientes da LM e da LE pode resultar em uma produçáo escrita inadequada em termos de LE. No entanto, ao constatarmos que os aprendizes estâo fazendo uso dessa estratégia, atestamos que o desenvolvimento da competência comunicativa está avançando. Isso porque, constata-se que a aprendiz ao adequar a estrutura da sua LM à LE está se tornando relativamente autônomo, uma vez que busca recursos que o auxiliem no ato comunicativo. 
Em (03), o elemento linguístico "Segundo" indica a expressāo de valor mediativo e mostra que houve imputaçăo do PdV a "O'Malley et al (1985)". Em seguida, L1/E1 acrescenta o seu comentário e, com esforço, responde a algo que possa năo ter ficado claro na formulaçăo textual daquele PdV. O elemento "Em outras palavras" introduz a reformulaçăo, que encena o desdobramento reflexivo do dizer a partir da figura de "respostas de fixaçăo de um sentido" (AUTHIER-REVUZ, 1998, p. 25). L1/E1 assume o esforço de dizer melhor, de eliminar qualquer falha na relaçăo entre as palavras e elas mesmas, acrescentando a descriçăo metaenunciativa do sentido de uma unidade textual posta no fio do discurso, qual seja: o papel da língua materna no contexto de aprendizagem de uma língua estrangeira. Por isso mesmo, entendemos que L1/E1 expressa engajamento em relaçăo ao PdV alheio.

Ademais, neste recorte do Ac03, L1/E1 assume explicitamente "o posicionamento teórico de Oxford (1990 apud VILAÇA, 2010, p. 211)" para responder a questăo levantada sobre "o que seria uma estratégia de aprendizagem". Assim, seu posicionamento é de acordo total em relaçáo ao PdV imputado, via $\mathrm{DD}$, a e2, tanto é que o toma como respaldo para afirmar que "nesse sentido, a combinaçăo das gramáticas provenientes da LM e da LE pode resultar em uma produçâo escrita inadequada em termos de LE". A princípio, esta afirmaçáo parece náo estabelecer relaçáo direta com as palavras de Oxford, mas no trecho destacado em negrito, no final do parágrafo, os dados constatados em pesquisa corroboram o conceito de estratégia de aprendizagem citado.

(04)

Assim, a mídia acaba por ofertar modelos de identidades através de processos de imitaçâo e formas ritualizadas. "Socialmente úteis, as matrizes identitárias estabelecem paradigmas, estereótipos, maneiras de agir e pensar que simbolicamente inserem os sujeitos em uma 'comunidade imaginada'." (GREGOLIN, 2008, p. 95). É a língua inglesa como padrăo mundial de comunicaçăo (mais uma vez, devido à globalizaçăo), trazendo seus paradigmas e estereótipos. Se o indivíduo fala inglês, pertence a uma "comunidade imaginada" dos que falam inglês e goza dos privilégios que gozam os pertencentes a este grupo.

(Ac04, 2012, p. 270)

Em (04), L1/E1 fala do modo como a mídia "acaba por ofertar modelos de identidades" e como a língua inglesa, inscrita na mídia publicitária, contribui para que isso se efetive. No primeiro trecho em destaque, juntamente com o sistema autor/data/ página, as aspas delimitam um ato de enunciaçăo citado, como uma espécie de DD, mas sem o elemento introdutor. Para este caso, dizemos que o elemento $X$, isto é, o PdV alheio, foi citado com todas as suas precisóes sintáticas, como um exterior apropriado ao discurso de L1/E1, dando-lhe apoio teórico. No segundo trecho, em "comunidade imaginada", as aspas também marcam uma exterioridade, a presença de uma palavra pertencendo a um outro PdV, propriamente o de "Gregolin (2008)".

Podemos deduzir que, nos dois exemplos de uso das aspas, há engajamento enunciativo por parte de L1/E1. No primeiro, há um certo grau de assunçăo pelo PdV de Gregolin, pois, mesmo na objetividade aparente, L1/E1 compartilha-o, assimila-se a ele. Está claro 
que as aspas separam os dois atos de enunciaçăo, porém o PdV alheio se mostra integrado sintaticamente como continuaçáo do PdV de L1/E1, desenvolvendo-o, dando-lhe o apoio em palavras e em conteúdo (e2 falando no lugar de L1/E1). No segundo, vemos que L1/E1 mantém as aspas já usadas para destacar o termo "comunidade imaginária" no PdV de "Gregolin (2008)". Esta pequena porçăo do texto foi proferida e preservada como pertencendo a outro locutor-enunciador, mas com o qual L1/E1 está em sintonia.

Assim, o exemplo (04) evidencia uma enunciaçăo que especifica um tipo de fronteira entre si e o outro, mostrando esse outro na cadeia significante, no âmbito da náocoincidência do discurso consigo mesmo, com indícios de engajamento de L1/E1, pelo fato de utilizar o PdV alheio como apoio teórico.

(05)

\section{Fundamentaçâo teórica}

2.1 Importância da leitura do năo verbal

O Século XX tem sido considerado por muitos como sendo o século da imagem, ou seja, aquele que registra, informa e expressa os acontecimentos, fatos, ideias e apreensōes com impacto e rapidez impensáveis. A internet está aí para comprovar e esboçar um primeiro retrato falado do século XXI.

Nas sociedades contemporâneas, cada vez mais, a imagem se infiltra nos sistemas de comunicaçấo e educaçâo. Assim, torna-se praticamente impossível deixar de lado as preocupaçóes com a alfabetizaçăo visual do cidadăo.

(Ac05, 2012, p. 256)

Em (05), temos uma pequena parte de uma das seçôes teóricas do Ac05. Nela, ocorre a nâo-coincidência do discurso consigo mesmo, pois há um tipo de outro demarcado na materialidade textual: outro discurso (corresponde ao que "muitos" têm considerado) e outra época (as "sociedades contemporâneas"). É esse outro e essa temporalidade que funcionam como figuras que separam o dizer de L1/E1 e de e2, indicando a quem incide a responsabilidade pelas duas informaçōes relatadas: a denominaçăo de "século da imagem" para referir-se ao século XX e à capacidade que tem a imagem de se infiltrar nos sistemas de comunicaçăo e educaçáo. Trata-se, pois, de um contexto de imputaçâo do PdV, em que outros locutores-enunciadores (indefinidos textualmente) e outra época sâo as fontes enunciativas.

Há também marcas linguísticas de nâo-coincidência das palavras com elas mesmas, quando o autor do Ac05 emprega o introdutor de reformulaçáo "ou seja", emitindo aquilo que se denomina como resposta de fixaçấo do sentido, com base em AuthierRevuz (1998). Ele realiza uma paráfrase do termo "século da imagem" por meio de uma expressâo sintaticamente mais desenvolvida, qual seja: [o século da imagem é] "aquele que registra, informa e expressa os acontecimentos, fatos, ideias e apreensóes com impacto e rapidez impensáveis". Nessa porçâo textual, L1/E1 demonstra seu engajamento, no sentido de esforçar-se para esclarecer o PdV alheio e também para validá-lo, dizendo que "A internet está aí para comprovar e esboçar um primeiro retrato falado do século XXI" e concluindo: "Assim, torna-se praticamente impossível deixar de lado as preocupaçôes com a alfabetizaçâo visual do cidadâo". 


\section{Análises}

$[\ldots]$

Conforme esclarecemos anteriormente, um dos objetivos do nosso curso, além da produçâo textual, era a análise linguística (AL). Como Kemiac e Lino de Araújo (2011) afirmam, a AL é uma alternativa para o ensino tradicional de gramática, baseando-se em uma concepçăo de ensino, objeto de ensino e metodologia diferentes. Neste ponto, ainda quanto a $\mathrm{AL}$, Mendonça (2006) sintetiza que:

AL é parte das práticas de letramento escolar, consistindo numa reflexăo explícita e sistêmica sobre a constituiçáo e o funcionamento da linguagem nas dimensôes sistêmica (ou gramatical), textual, discursiva e também normativa [...]. (MENDONÇA, 2006, p.208).

Avaliamos que ao invés de classificar e identificar, como no ensino de gramática tradicional, a AL se propóe a refletir. Foi o que procuramos fazer em nossas aulas, como na aula sobre os adjetivos, na qual utilizamos o texto "Mulher boazinha" de Martha Medeiros, para trabalhar com os alunos a funçâo que os adjetivos exerciam dentro do texto, a recorrência desse recurso no diminutivo.

(Ac06, 2012, pp. 279-280)

Este recorte da seçăo de análise do Ac06 traz duas marcas linguísticas do MED que sinalizam graus diferentes de indicaçâo da responsabilidade enunciativa. Na passagem "Como Kemiac e Lino de Araújo (2011) afirmam, a AL é uma alternativa para o ensino tradicional de gramática, baseando-se em uma concepçăo de ensino, objeto de ensino e metodologia diferentes", observamos que L1/E1, ao menos à primeira vista, se distancia, năo assume o conteúdo relatado. Logo em seguida, traz a visăo de "Mendonça (2006)" na forma de um DD com "que". No comentário que segue a essas formas de discurso relatado, L1/E1 cria a seguinte oposiçấo: A e B pensam (ou dizem) que X; nós (que seguimos A e B) avaliamos que Y. Detalhando um pouco mais essa oposiçăo, temos as seguintes atitudes de L1/E1:

- pronuncia-se sobre AL como (conforme) Kemiac e Lino de Araújo afirmam;

- expóe o modo tal qual Mendonça (2006) sintetiza a AL;

- emite posicionamento contrário ao que outros autores dizem/fazem sobre e no ensino de gramática tradicional (nâo concorda que a análise linguística se reduza a identificar e classificar elementos gramaticais);

- emite posicionamento favorável em relaçâo ao que Kemiac e Lino de Araújo (2011) teriam afirmado e ao que Medonça (2006) sintetizou sobre a AL, ou seja, o autor do Ac06 concorda que a AL conduz à reflexáo sobre a língua, tanto é que aplica esse conceito para fundamentar sua própria prática de ensino.

O engajamento de L1/E1 em relaçăo aos PdV imputados a e2 (os autores citados) está evidente no parágrafo final do excerto, quando diz: "Avaliamos que ao invés de classificar e identificar, como no ensino de gramática tradicional, a AL se propóe a refletir. Foi o que procuramos fazer em nossas aulas, [...]". 


\section{Introduçấo}

O ensino de língua portuguesa no Brasil é marcado por uma tradiçáo que tem profundas raízes históricas. Batista (1991) nos mostra que a disciplina gramática nacional surge no final do Império a partir de um processo de transmissăo de um patrimônio cultural, com o propósito de formar uma identidade linguística que consolidaria a unidade política e geográfica da Naçăo. Porém, a esse projeto de homogeneizaçăo se contrapóe uma real diversidade e heterogeneidade tanto das práticas linguísticas quanto culturais no espaço nacional. Desse modo, o ensino de língua passou a ter um caráter disciplinador, normatizador e homogeneizador das características linguísticas e culturais dos alunos, pautado na ideia de correçâo. A Gramática Normativa passa, entăo, a ser o instrumento dessa prática; e a escola, o principal meio pelo qual esse "ideal de língua" se firma e se consolida.

Nesse quadro tradicional do ensino de língua materna, Britto (2001), após constatar que o nível de escrita dos estudantes brasileiros está muito abaixo do satisfatório, questiona a prática artificial de produçáo de redaçóes na escola. Isso porque, ao se tomar como único interlocutor o professor (que representa a figura social da escola), essa produçáo náo constitui um processo real de interaçăo; ou seja, o estudante fala para "ninguém", ou náo sabe para quem fala. Portanto, na tentativa de agradar ao professor e visando à nota, os alunos escrevem de acordo com a imagem de língua daquele, o que os faz associarem a concepçáo de língua a um modelo formal preexistente às suas reflexóes e escolhas. Além disso, o texto, muitas vezes, segue um padrâo previamente estabelecido e/ou funciona como um pretexto para aplicaçáo das liçóes de gramática estudadas.

$[\ldots]$

(Ac07, 2012, p. 289)

Em (07), reproduzimos toda a parte da introduçấo do Ac07 onde ocorrem contextos de imputaçấo de PdV. Entre as marcas linguísticas identificadas no excerto está a ilhota textual em DI. O termo ou grupo de palavras "gramática nacional" (isolado em itálico) encontram-se no interior da formulaçăo textual do DI introduzido por "Batista (1991) nos mostra que", significando que é um termo usado pelo autor citado e que năo foi traduzido, parafraseado, na sintaxe de L1/E1. Nesse exemplo, observamos o distanciamento enunciativo, configurando o que Authier-Revuz (1998, p. 142) designa de "apenas um caso de imagem particular do funcionamento do sinal de modalizaçăo autonímica". Isso ocorre porque L1/E1 integra sintaticamente o elemento isolado em itálico ao seu próprio ato enunciativo (o citante), conservando-o tal como foi empregado na mensagem de origem. A ilha textual em DI evidencia, pois, que há uso com mençăo das palavras alheias.

As marcas linguísticas de DI também se apresentam em "Nesse quadro tradicional do ensino de língua materna, Britto (2001), após constatar que [...], questiona [...]", onde L1/E1 relata um PdV alheio com palavras próprias. No comentário desenvolvido em relaçăo aos PdV de e2, é possível verificar fenômenos de modalizaçăo autonímica: 
- A palavra "ideal de língua" está funcionando como marca de năo-coincidência do discurso consigo mesmo, pois assinala a "interdiscursividade representada - de uma fronteira interior/exterior" (AUTHIER-REVUZ, 1998, p. 23). Mais precisamente, trata-se de uma palavra retomada de um outro discurso do qual se fala na enunciaçăo de L1/E1 (o da gramática tradicional).

- Os termos "ou seja" e "ninguém" configuram duas formas distintas de dar respostas de fixaçăo de um sentido, no âmbito da năo-coincidência das palavras com elas mesmas. Com o "ou seja", L1/E1 apresenta a especificaçâo positiva do sentido de uma unidade sintática por meio da paráfrase ("essa produçâo nâo constitui um processo real de interaçăo" no sentido de "o estudante fala para 'ninguém'"). Nessa formulaçăo parafrástica, L1/E1 assume o esforço de destacar, por meio das aspas, que o sentido de "ninguém" náo está dado na sua literalidade (= nenhuma pessoa), mas dizendo respeito à ausência de interlocutores reais e autênticos (nâo apenas o professor) para a produçăo textual realizada na escola.

O olhar sobre a dimensáo macro dos casos de imputaçăo apresentados em (07) revela que L1/E1 distancia-se das raízes históricas que constituem o discurso tradicional de ensino de língua portuguesa no Brasil e aproxima-se de um discurso mais atual, retomado de "Brito (2011)". Assim, cria laços de responsabilizaçăo com este outro locutor-enunciador, questionando também, em seu próprio ato de anunciaçăo, "a prática artificial de produçâo de redaçôes na escola" e considerando a língua em sua "real diversidade e heterogeneidade".

(08)

\subsubsection{As condiçôes de produçâo como tentativa de conter sentidos}

[...]

Tomando emprestadas as palavras de Orlandi (2004, p. 67), podemos afirmar que,

para que a língua faça sentido é preciso que a história intervenha. E com ela o equívoco, a ambigüidade, a opacidade, a espessura material do significante. Daí a necessidade de administrá-la, de regular as suas possibilidades, as suas condiçóes. A interpretaçâo, portanto, nâo é mero gesto de decodificaçāo, de apreensâo do sentido. Também náo é livre de determinaçôes. Ela năo pode ser qualquer uma e nâo é igualmente distribuída na formaçăo social.

0 que Orlandi nos apresenta, nada mais é do que uma constataçăo de que, apesar de a linguagem ser aberta, essa "polissemia" tenta ser controlada. Em um texto, por exemplo, uma forma de conter sentidos é através do uso das notas de rodapé6. No livro que tomamos como objeto de análise, o que nos chama a atençáo é o fato de as produçóes textuais dos alunos serem "administradas" por coletâneas de texto, os painéis de leitura, e serem acompanhadas por uma longa e detalhada descriçáo de como devem ser.

[...]

Nota de rodapé:

${ }^{6}$ Cf. Orlandi, 1990, p. 106.

Ac08, 2013, pp. 424-425 
Assim como nos demais excertos, neste recorte da análise de dados do Ac08, a expressâo do acordo pós imputaçăo está explícita, onde vemos que L1/E1 toma emprestadas as palavras de "Oldandi (2004, p. 67)", para tratar sobre como a língua produz sentidos, como se constitui a interpretaçáo. Em seguida comenta, explica as palavras citadas e se pauta nelas para fundamentar seu olhar sobre dados de pesquisa.

As ocorrências de imputaçáo com acordo nos artigos científicos do pesquisador iniciante nos chamam a atençâo para a necessidade de um olhar que nâo tome de forma isolada as marcas linguísticas indicadoras da responsabilidade enunciativa na materialidade textual. Vimos que nem sempre imputar um PdV a outrem significa a nâo assunçâo ou o náo engajamento pelo seu conteúdo proposicional. Aqui, o campo científico a que esse gênero se vincula aceita plenamente a possibilidade de uma "atitude valorizante" em relaçâo ao que o outro diz (RABATEL, 2013). Se uma das partes desse gênero tem como propósito apresentar os postulados teóricos que embasaram a análise/interpretaçâo de dados, em um espaço previamente estabelecido, é pouco provável que o pesquisador principiante se dedique a questionar ou refutar a teoria. No fio textual do discurso, ele faz com que as vozes convocadas se tornem "aliadas", atuando como um co-enunciador em relaçăo a elas, em um cenário de responsabilizaçăo compartilhada que lhe favorece.

\section{A responsabilizaçáo náo compartilhada - posiçăo de desacordo no ato da imputaçăo}

Nos artigos científicos dos pesquisadores iniciantes, constatamos situaçóes em que L1/E1 atribui o PdV a e2 e em seguida assinala explicitamente seu posicionamento desfavorável. Săo ocorrências em que L1/E1 reconhece o PdV de e2, mas năo se assimila a ele, năo concorda, exibindo uma espécie de grau máximo de năo engajamento. Em outras palavras, tratam-se de $\mathrm{PdV}$ alheios com responsabilizaçăo năo compartilhada, em que o reconhecimento do PdV de e2 por parte de L1/E1 move-se na direçáo da nâo assunçâo. No total de oito artigos científicos analisados, identificamos ocorrências de imputaçáo com desacordo apenas em dois, o Ac07 e o Ac08, como mostramos a seguir.

\section{(09)}

Sua prática, na turma do $3^{\circ}$ ano $\mathrm{C}$ do ensino médio, predominantemente consistia em copiar regras da gramática tradicional ou questôes sobre gramática no quadro. Durante mais de três aulas, a professora se encarregou de expor e explicar regras de ortografia. Ela lia o conceito, dava exemplos para testar a validade da regra e pedia exemplos para os alunos. Diante das dificuldades dos alunos de entenderem a terminologia e os empregos linguísticos considerados "corretos" (já que era feito um trabalho de metalinguagem referente a uma variedade de língua da qual eles nâo săo falantes: a variedade padrâo), a professora repetia incessantemente: "Prestem atençâo! Vocês que vâo fazer redaçâo tem que colocar isso na cabeça!"; "Isso é uma regra que, se a gente quer escrever certo, tem que ter na cabeça".

Essa situaçâo, portanto, evidencia claramente um ensino voltado para a apropriaçâo da norma padrâo com vistas à escrita correta, o que revela uma prática baseada na concepçấo de linguagem como código, visto que podemos inferir que a professora, por meio da atividade, encara a língua como o conjunto homogêneo de suas formas estanques. 
A insistência em se estudar regras de ortografia faz com que os alunos introjetem a visáo dicotômica de "certo x errado", sendo o errado permitido na fala e o certo obrigatório na escrita, como se pode ver quando afirma: "Todo mundo pode errar falando, mas escrevendo, nâo!". Ao invés de considerar a ortografia procurando interpretar o desvio da norma enquanto um lugar privilegiado para a descriçáo dos fatos da língua, identificando as diferenças entre as modalidades escrita e falada e discutindo os fenômenos da variaçáo linguística, a docente defendia a ideia dicotômica de fala e escrita, incorrendo numa inconsistência teórica em relaçăo a essas modalidades, pois, segundo Marcuschi (2008):

oralidade e escrita sâo práticas e usos da língua com características próprias, mas náo suficientemente opostas para caracterizar dois sistemas linguísticos nem uma dicotomia. Ambas permitem a construçâo de textos coesos e coerentes, ambas permitem a elaboraçăo de raciocínios abstratos e exposiçôes formais e informais, variaçôes estilísticas, sociais dialetais e assim por diante. As limitaçôes e os alcances de cada uma estâo dados pelo potencial do meio básico de som e grafia. Em suma, eficácia comunicativa e potencial cognitivo năo sâo vetores relevantes para distinguir oralidade e escrita. (p. 17).

Desse modo, a professora acaba limitando a ideia de texto às características ditas da modalidade escrita, privando os alunos do entendimento mais amplo em relaçâo a essas duas modalidades da língua.

(Ac07, 2012, pp. 295-296)

Neste recorte do Ac07, há vozes de locutores-enunciadores distintos explícitos na materialidade textual: o pesquisador/produtor do artigo científico, os autores citados para fundamentar teoricamente o trabalho (especificamente "Marcuschi") e o informante da pesquisa (uma professora de língua portuguesa), além dos alunos da professora. Aqui, nâo nos interessa as açóes da professora, mas somente os PdV que, segundo o relato de L1/E1, ela teria proferido em sala de aula e com os quais ele discorda completamente, como apresentamos resumidamente no quadro 3.

\section{Quadro 3: Gerenciamento dos PdV conforme o excerto 9}

\begin{tabular}{c|c}
\hline PdV de e2 (a professora) & Refutação dos PdV de e2 por L1/E1 \\
\hline $\begin{array}{c}\text { Os alunos precisam ter atenção sobre as } \\
\text { regras gramaticais, porque farão redação } \\
\text { e precisam estar com elas na cabeça para } \\
\text { escrever correto. }\end{array}$ & $\begin{array}{c}\text { E2 adota uma concepção equivocada de língua/linguagem. } \\
\text { E2 apresenta uma visão dicotômica de certo } x \text { errado e isso } \\
\text { prejudica os alunos. }\end{array}$ \\
\hline $\begin{array}{c}\text { Na fala, se pode errar; na escrita, não. } \\
\text { E2 desvia o foco: dá mais atenção a erros gramaticais e menos à } \\
\text { análise de elementos linguísticos e fenômenos de variação. } \\
\text { E2 apresenta uma visão dicotômica de fala e escrita, revela } \\
\text { inconsistência teórica. }\end{array}$ \\
$\begin{array}{c}\text { E2 confunde a ideia de texto com características da escrita formal. } \\
\text { E2 prejudica a compreensão ampla dos alunos. }\end{array}$ \\
\hline
\end{tabular}

Fonte: elaboração própria

Nesse caso, a refutaçâo dos PdV se dá na medida em que o autor do Ac07 demonstra sua capacidade crítico-analítica ao descontruir uma prática de ensino que se mostra em dissonância com os postulados teóricos que ele adota em sua pesquisa. 
Vejamos como isso ocorre voltando nosso olhar ao capítulo 13, "A carta de leitor". Ao propor que o aluno produza uma carta, o livro primeiramente apresenta um texto base que trata do desmatamento na Amazônia. Em seguida, oferece a seguinte proposta de produçăo:

Imagine que você tenha lido essa reportagem na revista e queira se manifestar em relaçâo a algo que lhe tenha chamado a atençâo. Escreva entăo uma carta para o editor responsável pela revista ou para o jornalista que assinou a matéria.

Você pode, por exemplo, comparar o novo sistema de registro de desmatamento comentado pela revista a outras medidas anunciadas pelos governantes como capazes de levar a soluçóes milagrosas, mas, na realidade, ineficientes. Pode também comentar o enfoque dado ao tema, elogiando ou criticando a maneira como o assunto foi tratado. (CEREJA; MAGALHÂES, 2005, p.144, grifo nosso)

Compreendemos que os autores do livro didático vâo muito além de oferecer as condiçōes de produçăo ao aluno. Ao sugerir que o aluno compare "o novo sistema de registro de desmatamento comentado pela revista a outras medidas anunciadas pelos governantes", o livro direciona o olhar do aluno para um aspecto da matéria sobre a Amazônia, ou seja, silencia outras interpretaçôes. Além disso, ao qualificar essas ditas "soluçóes milagrosas" do governo como "ineficientes", o livro adota o ponto de vista defendido pelo autor da matéria, que julga "ineficientes" todos os investimentos do governo na preservaçáo dessa floresta.

Pela nossa análise, é possível constatar que o trabalho com a produçăo de textos argumentativos, assim como já demonstramos com as questôes de "interpretaçâo", é bastante limitado, já que, quando aparece, é mediado pelos autores do livro para que o sentido seja apenas um, evitando-se assim, uma interpretaçăo "equivocada" por parte do aluno. Em outro capítulo analisado, "As cartas argumentativas de reclamaçăo e de solicitaçăo", também encontramos esse "excesso" de detalhamento nas propostas de produçấo textual:

(Ac08, 2013, p. 425)

Em (10), L1/E1 emite seu posicionamento desfavorável na direçăo de desconstruir a postura do livro em relaçấo ao tratamento da produçâo textual, como demonstramos no quadro abaixo, para efeito de síntese.

\section{Quadro 4 - Gerenciamento dos PdV conforme o excerto 10}

\begin{tabular}{c|c}
\hline PdV de e2 (o livro didático) & Refutação do PdV de e2 por L1/E1 \\
\hline $\begin{array}{c}\text { O aluno produz o texto argumentativo ao serem dadas } \\
\text { as condições de produção, que incluem fornecer texto } \\
\text { base e apresentar o direcionamento do tema e do ponto } \\
\text { de vista. }\end{array}$ & $\begin{array}{r}\text { E2 silencia outros sentidos possíveis à abordagem do } \\
\text { tema e limita o ponto de vistas dos alunos. }\end{array}$ \\
\hline
\end{tabular}


Sobre os contextos de imputaçăo aqui analisados, chamamos atençăo para o fato de que o posicionamento de desacordo tem respaldo, implícita ou explicitamente, em outros PdV alheios, os de autores representativos da teoria adotada nos artigos científicos (por exemplo, "Marcuschi", visto no excerto 09)

Considerando os excertos apresentados, podemos reiterar que uma das maneiras de a imputaçăo suscitar a nâo assunçăo pelo conteúdo proposicional de um PdV é nas situaçōes em que L1/E1 manifesta seu desacordo, ou seja, năo deixa qualquer indício de engajamento, de comprometimento em relaçâo ao que o outro disse, pensa ou defende. Essa operaçăo, no entanto, nâo foi o que predominou, nem teve significativa frequência nos artigos científicos dos pesquisadores iniciantes. Dada a sua posiçăo no campo científico, o pesquisador iniciante, sobretudo este a que estamos nos referindo (o aluno de graduaçáo), se configura como um sujeito que se limita a reproduzir o saber e o aplica para a descriçâao e/ou interpretaçăo de dados da realidade. Embora óbvio, esse dado é um indicador da necessidade de se relativizar as imposiçóes que se costumam atribuir a esses estudantes, que certamente precisam de mais tempo de formaçăo acadêmica para compreender o funcionamento do campo científico, as variadas espécies de gêneros de discurso que nele se situam, inclusive com suas hierarquias e contradiçóes, os conceitos, postulados e procedimentos metodológicos da teoria adotada, entre muitos outros aspectos.

\section{PdV anônimos e os indícios de uma pseudoneutralidade}

Considerando o aporte teórico aqui adotado, entre as formas de materializar a nâo assunçấo da responsabilidade enunciativa está a expressâo de neutralidade. Seria uma espécie de grau zero de indicaçâo deste fenômeno, já que năo fica evidente quem é o responsável pelo $P d V$, cujo conteúdo proposicional é relatado objetivamente em terceira pessoa, "de forma neutra", como diz Rabatel (2009), e corresponde ao que Adam (2011) designa como PdV anônimo. Essa é uma prática muito comum na escrita acadêmico-cientifica, mas, na verdade, trata-se de uma "pseudoneutralidade", porque, por mais objetivo e distanciado que se mostre L1/E1, a própria opçăo de usar a terceira pessoa verbal já aponta um posicionamento subjetivo, por exemplo, o de náo se revelar, năo se comprometer com o PdV, atribuindo-o à opiniăo comum, pertencente ao campo científico.

Semelhante aos casos de imputaçăo analisados anteriormente, a "neutralidade" supóe que houve um reconhecimento por parte de L1/E1 do PdV de e2, que desta vez é um locutor-enunciador anônimo. A diferença é que L1/E1 năo demonstra rejeitar ou aceitar o PdV alheio como válido, correto, incorreto, bom, ruim etc., ficando na situaçáo intermediária entre a assunçăo e a năo assunçăo.

Seguem abaixo três entre as ocorrências identificadas no corpus e que constituem, pois, o que estamos considerando como PdV anônimos e como expressăo de um posicionamento neutro de L1/E1. 
Para que o conhecimento de mundo efetive-se de forma satisfatória na vida do profissional de redaçâo e revisâo, faz-se necessário que ele saiba distinguir e usar adequadamente os gêneros textuais. Vale lembrar que gêneros textuais sâo tipos específicos de textos de diferentes naturezas, sejam eles literários ou nâo. As formas textuais (tipos de texto) constituem-se nas materialidades linguísticas reconhecidas socialmente: narrativas, argumentativas, descritivas, injuntivas, expositivas e dialogais, que circulam por meio de diversos gêneros textuais. Sob essa concepçâo, pode-se citar alguns exemplos de gêneros: anúncios, convites, atlas, avisos, programas de auditórios, bulas, cartas comerciais, cartazes, comédias, contos de fadas, crônicas, editoriais, ensaios, entrevistas, ofícios, decretos, discursos políticos, histórias, instruçôes de uso, letras de músicas, leis, mensagens, notícias. Sâo textos que circulam em vários setores e têm uma funçâo específica discursiva, sendo voltados para um público distinto e com características próprias. Segundo Marcuschi,

o estudo dos gêneros textuais é uma fértil área interdisciplinar, com atençáo especial para o funcionamento da língua e para as atividades culturais e sociais. Desde que năo concebamos os gêneros como modelos estanques nem como estruturas rígidas, mas como formas culturais e cognitivas de açáo social corporificadas de modo particular na linguagem, veremos os gêneros como entidades dinâmicas. Mas é claro que os gêneros têm uma identidade e eles sáo entidades poderosas que, na produçăo textual, nos condicionam a escolhas que năo podem ser totalmente livres nem aleatórias, seja sob o ponto de vista do léxico, do grau de formalidade ou da natureza dos temas, como bem lembra Bronckart (2001). Os gêneros limitam nossa açấo na escrita. [...] Pois, assim como a língua varia, também os gêneros variam, adaptam-se, renovam-se e multiplicam-se. Em suma, hoje, a tendência é observar os gêneros pelo seu lado dinâmico, processual, social, interativo, cognitivo, evitando a classificaçáo e a postura estruturais. (MARCUSCHI, 2011, p. 18-19, grifos do autor).

(Ac02, 2012, pp. 233-234)

Devido à forma impessoal do verbo, năo está explícito quem assume o conteúdo que incide sobre "Vale lembrar" e "Sob essa concepçăo, pode-se citar". Todavia, como defendemos a ideia de uma pseudoneutralidade, é apenas provisoriamente que o anonimato do PdV se mantém no texto. Em primeiro lugar, para estes exemplos, admitimos a hipótese de uma "dupla voz" (PASSEGGI et al., 2010, p. 304): a voz advinda da teoria adotada no artigo científico (a teoria de gêneros, trazida pela mediaçăo de "Marcuschi" e de outros autores) e a voz do autor do Ac02, que julga relevante lembrar ao seu leitor alguns aspectos sobre a natureza dos gêneros textuais. Em segundo lugar, concordamos com Rabatel (2009) quando afirma que todo PdV imputado requer uma posiçấo de L1/E1. Náo importa se imputado a uma opiniáo comum, a uma fonte anônima, o fato é que o discurso cobra uma posiçấo daquele que profere o enunciado.

Ora, como mostramos anteriormente, predomina a manifestaçăo de acordo em relaçấo à teoria de base adotada nos artigos científicos analisados, o que sugere que L1/E1 compartilha a responsabilidade pelos PdV imputados a e2. Assim, o exame do contexto linguístico, como sugere Adam (2011), assegura que o conteúdo desses PdV aparentemente anônimos em (11) se encontra relacionado a um ou outro e2 citado no Ac02. 
O estudo de caso empreendido também nos levou a concluir, a partir da análise da produçáo escrita de alunos adultos, que a combinaçáo gramatical pode refletir um lapso cometido pelo aluno que ainda năo se acostumou com as convençôes gramaticais da LE. Nesse sentido, a aprendizagem de LE é entendida com um processo em que o indivíduo precisa se desvincular gradualmente das estruturas de sua LM para, entăo, tornar-se proficiente na LE aprendida.

Cabe questionar entăo, em que medida essa combinaçăo gramatical funciona efetivamente como uma estratégia de aprendizagem ou indica apenas uma distraçáo/dificuldade do aprendiz. Consideramos, portanto, que a resposta para esse questionamento é uma tarefa produtiva reservada para estudos futuros.

(Ac03, 2012, p. 263)

A mobilizaçâo do verbo na forma impessoal em "Cabe questionar" torna o PdV anônimo, pois náo evidencia quem questiona. Porém, ao deixar a resposta em aberto, o autor do Ac03 revela ser o locutor-enunciador da questăo, que foi levantada por ele como forma de conduzir a reflexăo acerca dos resultados obtidos na pesquisa. Nesse exemplo, consideramos também a possibilidade da voz dupla, tendo em vista que L1/ E1 formula um questionamento levantado pela própria teoria de aquisiçăo de segunda língua adotada por ele no Ac03.

(13)

Ao considerar que a mídia tem uma grande parcela de participaçâo no processo de formaçâo de identidade, pode-se afirmar que ela é fonte para uma análise da identidade dos sujeitos para os quais ela se dirige. Portanto, analisar a língua utilizada na mídia possibilita, também, enxergar traços da identidade desse sujeito que ela almeja alcançar.

(Ac04, 2012, p. 265)

Nesse trecho específico do Ac04, năo está evidente o locutor-enunciador que assume pelo PdV de que "a mídia tem uma grande parcela de participaçáo no processo de formaçăo de identidade" e de que "ela é fonte para uma análise da identidade dos sujeitos para os quais ela se dirige". O contexto linguístico, dito e implicitado, é o que nos orienta a perceber que se trata de postulaçôes assumidas pelo autor do Ac04, com base na teoria adotada. Essas duas postulaçôes embasam o seu olhar para analisar o papel da mídia na construçăo de identidades.

A análise das ocorrências de PdV anônimos confirma o postulado de Rabatel (2009) de que a situaçăo intermediária da neutralidade, embora teoricamente possível, náo dura muito tempo. Como afirma o autor, o fato de L1/E1 se afastar do seu dizer nâo indica uma ausência de PEC, mas uma tática de legitimidade que consiste em se apoiar sobre um responsável externo11 (RABATEL, 2009, p. 77, traduçăo nossa).

11 [...] s'effacer de son dire n'indique pas une absence de PEC, mais une tactique de légitimation qui consiste à s'appuyer sur un garant externe. 
No contexto desta pesquisa, apontamos o campo científico, as condiçóes de produçăo e o próprio gênero de discurso como forças reguladoras dos atos enunciativos de L1/E1, exigindo a objetividade, o năo engajamento subjetivo. Em contrapartida, o funcionamento da linguagem reverte essa "ilusăo" e faz intervir, no fio textual/discursivo do gênero artigo científico, as marcas de um posicionamento teórico-metodológico assumido por seu autor. É nesse sentido que, na prática da relaçâo do locutor-enunciador com a linguagem, năo lhe é possível ficar o tempo todo neutro, sem tomar uma posiçấo no discurso.

Na tabela abaixo, apresentamos dados quantitativos que auxiliam a análise qualitativa aqui realizada e, portanto, nos dâo apoio para levantar algumas consideraçóes sobre os posicionamentos emitidos por L1/E1 nos artigos científicos.

Tabela 1: Posicionamentos enunciativos em contextos de imputação nos artigos científicos de pesquisadores iniciantes

\begin{tabular}{c|c|c|c|c}
\hline CÓD. & ACORDO & DESACORDO & NEUTRALIDADE & $\begin{array}{c}\text { OCORRENCIAS } \\
\text { POR ARTIGO } \\
\text { CIENTÍFICO }\end{array}$ \\
\hline Ac01 & 17 & 00 & 22 & 30 \\
\hline Ac02 & 34 & - & 14 & 37 \\
\hline Ac03 & 15 & - & 01 & 10 \\
\hline Ac04 & 30 & - & 05 & 32 \\
\hline Ac05 & 34 & - & - & 34 \\
\hline Ac06 & 13 & - & 07 & 29 \\
\hline Ac07 & 22 & 06 & 06 & 21 \\
\hline Ac08 & 16 & 02 & 56 & 212 \\
\hline Total & 149 & 08 & & \\
\hline
\end{tabular}

Fonte: elaboração própria

Os dados da tabela mostram que a posiçăo de acordo, representativos da expressâo de um laço de responsabilizaçấo com os PdV imputados, predomina nos artigos dos pesquisadores iniciantes (149 ocorrências), seguida da posiçăo intermediária de "neutralidade" (58 ocorrências). Já o desacordo, que supóe a refutaçăo de um PdV alheio, mostrou-se bem menos recorrente (apenas 8 ocorrências em dois artigos).

Na dimensăo mais macro da pesquisa de doutoramento, a identificaçăo das marcas linguísticas que sinalizam a imputaçăo foram o discurso direto, o discurso indireto, o discurso direto com "que", a modalizaçâo em discurso segundo, formas de nâo-coincidência do discurso consigo mesmo (sinalizadas com aspas e itálico), entre outras. Neste artigo, demonstramos que, no contexto linguístico em que alguns desses elementos foram utilizados, estabelecem um laço de responsabilizaçăo evidenciado em diferentes partes do plano de texto do artigo científico: na introduçâo, quando o L1/E1 apresenta qual a filiaçăo teórica do trabalho e anuncia quais os autores que seguirá; na seçăo teórica, quando se verifica que é feita uma síntese dos conceitos teóricos utilizados para fundamentar a análise de dados e, nos comentários acerca desses conceitos, L1/E1 reafirma os argumentos da teoria adotada (reproduz parafrasticamente o que ela diz, lhe dá validade e até enaltece, no sentido de torná-la importante). Já as demais posiçôes assumidas por L1/E1, o questionamento/refutaçâo da teoria e a pseudoneutralidade, 
ocorreram em pontos muito específicos, a maior parte das vezes em funçăo de uma palavra demarcada com aspas ou itálico sinalizando terminologia adotada por determinado autor, palavras de outra língua, ou palavras usadas por informantes da pesquisa.

\section{PALAVRAS FINAIS}

Conforme a análise feita, vimos que, ao imputar o conteúdo proposicional dos PdV a e2, mostrou-se mais recorrente a expressăo de posicionamentos favoráveis por parte de L1/E1, em situaçōes de retomadas, reformulaçōes e comentários que reafirmam e validam o dizer do outro. Assim, os resultados revelam que o pesquisador iniciante instaura uma forma de diálogo com os PdV alheios direcionado para a responsabilizaçấo compartilhada (acordo parcial ou total).

Esses dados sâo sugestivos para a análise da construçâo da autoria nos textos acadêmico-científicos dos pesquisadores situados na posiçấo de iniciantes. O foco sobre os movimentos de (nâo) assunçăo da responsabilidade enunciativa nos permitiu observar que esses pesquisadores constroem sua voz sob a dependência do dizer e, sobretudo, das palavras do outro (da teoria, de outros autores), tendo em vista os muitos contextos de imputaçấo com acordo, os PdV formulados com palavras importadas de e2 e assumidos como próprios por integraçăo sintática, as poucas constataçóes e comentários críticos particulares sobre o que esse outro diz, a ausência de explicaçôes e acréscimos, e uma análise de dados que também vai ao encontro da validade da teoria adotada.

Porém, é preciso dizer que esses resultados nâo podem ser compreendidos fora do contexto de produçâo dos artigos científicos ou deslocados em relaçăo à posiçăo na qual se situa seus autores. Trata-se de uma posiçăo relativa assumida por esses pesquisadores no campo científico e que por isso mesmo está sujeita a mudar, positivamente ou náo, a depender da experiência vivenciada ao longo da jornada acadêmica, das intervençóes recebidas de um profissional mais experiente durante o processo de escrita de textos e também das investidas individuais de sucesso e progresso.

Como contribuiçấo para uma experiência produtiva com o ensino de gêneros na graduaçăo que vise ao desenvolvimento de habilidades comunicativas do pesquisador iniciante no campo científico, especialmente o saber dialogar com o discurso do outro e assumir uma posiçâo enunciativa própria, os resultados da pesquisa também sâo sugestivos para a aplicaçăo didática de categorias linguísticas da responsabilidade enunciativa, a partir de um tratamento textual-discursivo das operaçôes de citaçáo no texto acadêmico, como propôs a pesquisa em sua versăo macro (BERNARDINO, 2015). 


\section{REFERÊNCIAS}

ADAM, J. M. A linguística textual: uma introduçâo à análise textual dos discursos. Traduçấo de Maria das Graças Soares Rodrigues et al. Revisâo Técnica: Joáo Gomes das S. Neto. 2 ed. revisada e aumentada. São Paulo: Cortez, 2011.

AUTHIER-REVUZ, J. Palavras incertas: as năo-coincidências do dizer. Traduçâo de Claudia R. Castellanos Pfeiffer, et al. Revisăo técnica da traduçăo Eni Pulccinelli Orlandi Campinas: Ed. da UNICAMP, 1998.

Heterogeneidade mostrada e heterogeneidade constitutiva: elementos para uma abordagem do outro no discurso. In: Entre a transparência e a opacidade: um estudo enunciativo do sentido. Apresentaçăo Marlene Teixeira; revisăo técnica da traduçâo de Leci Borges Barbisan e Valdir do Nascimento Flores. Porto Alegre: EDIPUCRS, 2004, pp. 11-80.

A representaçăo do discurso outro: um campo multiplamente heterogêneo. Traduçâo de Daniel Costa da Silva. Caleidoscópio, v. 6, n. 2, pp. 107-119, mai./ago. 2008.

BAKHTIN, M. Questōes de literatura e de estética: a teoria do romance. 5. ed. Săo Paulo: Editora Hucitec Annablume, 2002. Disponível em: <http://pt.scribd.com/doc/58069225/ Bakhtin-O-Discurso-No-Romance>. Acesso em: 21 mai. 2014.

. (VOLOCHÍNOV, V. N.). Marxismo e filosofia da linguagem. 12. ed. Traduçăo de Michel Lahud e Yara Frateschi Vieira. Sáo Paulo: Hucitec, 2006. (Original russo 1929). BERNARDINO, R. A. S. A responsabilidade enunciativa em artigos científicos de pesquisadores iniciantes e contribuiçóes para o ensino da produçăo textual na graduaçâo. 2015. 286 f. Tese (Doutorado em Estudos da Linguagem) - Universidade Federal do Rio Grande do Norte, Natal, RN, 2015. Disponível em: <https://repositorio.ufrn.br/jspui/ handle/123456789/21000>. Acesso em: 17 set. 2016.

FOUCAULT, M. 0 que é um autor? Traduçâo de António Fernando Cascais e Eduardo Cordeiro. 8 ed. Nova Veja: Limitada, 2012.

GUENTCHÉVA, Z. Manifestations de la catégorie du médiatif dans temps du français. Langue Française. n. 102, pp. 8-23, 1994.

NEVES, J. dos S. B. Corre voz no jornalismo do início do século XX: estudo semântico -enunciativo do Correio Braziliense e da Gazeta de Lisboa. Jundiaí: Paco Editorial, 2012.

PASSEGGI, L. et al. A análise textual dos discursos: para uma teoria da produçăo co(n) textual de sentido. In: LEITE, M. Q.; BENTES, A. C. (Orgs.). Linguística de texto e análise da conversaçâo: panorama das pesquisas no Brasil. Săo Paulo: Cortez, 2010, p. 262-312.

RABATEL, A. Le point de vue, une catégorie transversale. Le Français aujourd'hui, n. 151, p. 57-68, 2005. Disponível em: <http://www.cairn.info/publications-de-Rabatel -Alain--234.htm>. Acesso em: 04 jun. 2013.

Prise em charge et imputation, ou la prise em charge à responsabilité limitée... Langue Française - La notion de prise em charge em linguistique, n. 162, jun., pp. 3-27, 2009. 
. Schémas, techniques argumentatives de justification et figures de l'auteur (théoricien et/ou vulgarisateur). Revue d'anthropologie des connaissances, pp. 505-525, 2010.

O papel do enunciador na construçâo interacional dos pontos de vista. In: WANDER, E. (Org.). A construçáo da opiniâo na mídia. Traduçâo de Wander Emeditato. Belo Horizonte: FALE/UFMG, Núcleo de Análise do Discurso, 2013, pp. 19-66. 